\title{
Effect of feeding potato tubers modified by 14-3-3 protein overexpression on metabolism and health status of rats*
}

\author{
I. Kosieradzka ${ }^{1,5}$, E. Sawosz ${ }^{1}$, B. Pastuszewska ${ }^{2}$, M. Żuk ${ }^{3}$, J. Szopa ${ }^{3}$ \\ and W. Bielecki ${ }^{4}$
}

${ }^{1}$ Department of Animal Nutrition and Feed Science, Warsaw Agricultural University Ciszewskiego 8, 02-786 Warsaw, Poland

${ }^{2}$ The Kielanowski Institute of Animal Physiology and Nutrition, Polish Academy of Sciences 05-110 Jablonna, Poland

${ }^{3}$ Institute of Biochemistry and Molecular Biology, Wrocław University

Przybyszewskiego 63, 51-148 Wrocław, Poland

${ }^{4}$ Faculty of Pathology, Warsaw Agricultural University

Nowoursynowska 166, 02-787 Warsaw, Poland

(Received 20 October 2003; revised version 29 March 2004; accepted 6 April 2004)

\begin{abstract}
The effects of feeding rats transgenic potatoes with overexpression of 14-3-3 protein (line $J_{2}$ ) and repression of ADP ribosylation factor (line $\mathrm{J}_{1}$ ) and control potatoes (line Desiree) were compared. Potatoes of line $\mathrm{J}_{2}$ contained much more crude protein $(16.2 \%$ in $\mathrm{DM})$ in comparison with control potatoes $(10.7 \%)$ and transgenic line $\mathrm{J}_{1}$. Modification of 14-3-3 protein and ADP ribosylation also affected mineral composition, especially the Fe content. Feeding rats for 5 weeks with isoproteinous diets containing $20 \%$ dried transgenic or unmodified potatoes had no significant effect on the growth of the animals, did not negatively affect nutrient digestibility - the digestibility of fat and fibre in the diets containing tubers of transgenic lines $\mathrm{J}_{1}$ and $\mathrm{J}_{2}$, were higher, and a significantly higher digestibility of the organic matter of diets with $\mathrm{J}_{2}$ potatoes was found. The relative weight of selected internal organs, morphological parameters and most blood biochemical parameters did not differ significantly among the groups of rats fed diets containing dried transgenic and unmodified potatoes.
\end{abstract}

KEY WORDS: modified potato, digestibility, health status, rats

\footnotetext{
* Supported by the State Committee for Scientific Research, Grant No. 3 P06Z 00925

${ }^{5}$ Corresponding author: e-mail: Kosieradzka@delta.sggw.waw.pl
} 


\section{INTRODUCTION}

The introduction of genetically modified plant into common use should be preceded by comprehensive nutritional studies encompassing evaluation of the risk related to the possible toxic or allergenic effect of the modified food on the consumer. The application of genetic engineering techniques to the potato (widely used in human and animal nutrition in Poland) makes it possible not only to improve its agrotechnical characteristics but also to modify the chemical composition and nutritional value of the tubers. Changes in nutritional value may be an intentional or unintentional consequence of transgenesis, the result of changes in the activity of enzymes in key metabolic pathways, or changes in the concentrations of secondary metabolites.

In the described experiment, the synthesis of 14-3-3 protein one of key factor in plant metabolism protein, was enhanced in potato plants. The enhancement was achieved via two routes: by using the gene from Cucurbita pepo in its sense orientation (overexpression of 14-3-3 protein) and through repression of the potato gene for ADP-ribosylation of proteins (Żuk et al., 2003). Proteins from the 14-3-3 family act as coordinators of multiple signalling pathways (Aitken, 1996; Wilczyński et al., 1998a,b). Plant isoforms of this protein influence starch metabolism by regulating the activity of tyrosine and tryptophan hydroxylases, key enzymes in the synthesis of neurotransmitters, and regulate the activity of starch synthase (Sehnke et al., 2001). Moreover, these proteins influence the assimilation of carbon and nitrogen by regulating the activity of two key enzymes in these processes, namely sucrose phosphate synthase and nitrate reductase (Huber et al., 1996; Chung et al., 1999). It has also been shown that isoforms of 14-3-3 protein control the synthesis of amino acids and protein metabolism in plants (Szopa et al., 2001).

This study was undertaken to assess the advantages and potential risks resulting from feeding transgenic potatoes in which 14-3-3 protein synthesis is enhanced. In this study, the safety of using transgenic potatoes in diets was evaluated in compliance with European Union directives on rats as animals particularly sensitive to feed as a factor modifying metabolism and constituting an experimental model for humans and animals. The influence of a high proportion of transgenic potatoes in the diet on nutrient digestibility, growth, weight of internal organs as a parameter indicative of potential functional disorders, and on haematological indicators and selected biochemical parameters was studied.

\section{MATERIAL AND METHODS}

The experimental material comprised tubers of the potato, Solanum tuberosum L. cv. Desiree that were either unmodified or obtained through genetic transfor- 
mation in the direction of overexpression of genes responsible for the level of synthesis of 14-3-3 protein. Transduction was performed at the Department of Genetic Biochemistry of Wrocław University according to the method described by Szopa and Muller-Rober (1994) Wilczyński et al. (1998a); Szopa et al. (2001). The following types of transgenic plants were obtained:

$\mathrm{J}_{1}$ - potatoes with repression of the gene encoding protein ADP-ribosylation factor, resulting in elevated synthesis of 14-3-3 proteins. These potatoes showed an approximately $12 \%$ reduction of the fresh weight of tubers per plant,

$\mathrm{J}_{2}$ - potatoes overexpressing 14-3-3 protein from Cucurbita pepo var. patissonina, characterized by a higher number of tubers per plant and reduced fresh weight of tubers.

Such significant changes in the phenotypes of tubers (in the size of tubers and in the number of tubers per plant) can point to the significant influence of 14-3-3 proteins on the intensity of accumulating metabolic components in tubers and on the growth of the plant itself. For example, the regulatory effect of 14-3-3 protein on senescence was demonstrated (Markiewicz et al., 1996). The vegetation period of plants with an elevated 14-3-3 protein content was about two weeks longer and they flowered several times during growth. Opposing traits, i.e. shortening of the vegetation period, were observed in plants with antisense mutations of 14-3-3 protein.

The unmodified and transgenic plants were cultivated in individual containers in a greenhouse under a photoperiod of $16 \mathrm{~h}\left(22^{\circ} \mathrm{C}\right)$ light and $8 \mathrm{~h}\left(15^{\circ} \mathrm{C}\right)$ darkness. After 3 months the tubers were collected, divided into small parts, and dried at $50^{\circ} \mathrm{C}$. The dry matter, ash, total protein, crude fat and crude fibre contents of the dried tubers were determined according to AOAC procedures (1996). The analyses were carried out at the laboratory of the Department of Animal Nutrition and Feed Science of the Warsaw Agricultural University (SGGW). The contents of $\mathrm{Ca}, \mathrm{Mg}, \mathrm{Cu}, \mathrm{Zn}, \mathrm{K}$ and $\mathrm{Fe}$ were determined at the Department of Physicochemical Analyses of the SGGW by flame atomic absorption spectrometry, FAAS, Shimadzu, and the P content, by atomic emission spectrometry, ICP-AES.

The five-week nutritional experiment was conducted at the laboratory of the Institute of Animal Physiology and Nutrition of the Polish Academy of Sciences in Jabłonna on outbred IF:Jaz rats. Thirty-two male rats with an initial body weight of about $150 \mathrm{~g}$ were divided into four experimental groups, taking age and body weight into account. The animals were fed the experimental diets containing $20 \%$ dried transgenic potatoes and a control diet with $20 \%$ unmodified potatoes. The diets covered the animals' nutritional requirements according to NRC standards (1976). Table 1 presents the composition of the diets. The rats were housed in individual balance cages allowing intake control of feed, and maintained at a constant temperature of $21^{\circ} \mathrm{C}$, humidity of $60 \%$ and $12 / 12 \mathrm{~h}$ photoperiod. Every week the animals were weighed and feed consumption was recorded. Nutrient digestibility 
of the diets was determined in the final period of the experiment. Faeces were collected for 7 days, frozen and then dried, ground and analysed according to AOAC procedures (1996).

TABLE 1

Composition of the experimental diets, $\%$

\begin{tabular}{|c|c|c|c|}
\hline \multirow{3}{*}{ Item } & \multicolumn{3}{|c|}{ Diet - potatoes } \\
\hline & \multirow{2}{*}{$\begin{array}{c}\text { non-transgenic } \\
\text { Desiree }\end{array}$} & \multicolumn{2}{|c|}{ transgenic line } \\
\hline & & $\mathrm{J}_{1}$ & $\mathrm{~J}_{2}$ \\
\hline Potatoes & 20.0 & 20.0 & 20.0 \\
\hline Casein & 12.0 & 12.0 & 11.6 \\
\hline Cellulose & 3.2 & 3.2 & 3.3 \\
\hline Soya oil & 4.0 & 4.0 & 4.0 \\
\hline Vitamin $\operatorname{mix}^{1}$ & 2.0 & 2.0 & 2.0 \\
\hline Mineral mix $^{2}$ & 3.0 & 3.0 & 3.0 \\
\hline Dl-methionine & 0.1 & 0.1 & 0.1 \\
\hline Maize starch & 55.7 & 55.7 & 56.0 \\
\hline \multicolumn{4}{|l|}{ Crude } \\
\hline protein & 12.7 & 12.3 & 12.8 \\
\hline fat & 3.2 & 3.6 & 3.5 \\
\hline fibre & 2.9 & 3.2 & 3.2 \\
\hline ash & 3.9 & 3.9 & 3.8 \\
\hline
\end{tabular}

${ }^{1}$ according to AOAC (1975)

2 according to NRC (1976)

At the end of the experiment the rats were fasted for $12 \mathrm{~h}$, sedated by intramuscular ketamine at a dose of $50 \mathrm{mg} / \mathrm{kg}$ body weight and blood was sampled from the abdominal caval vein. The animals were euthanized by ketamine overdose and then the caecum, liver, pancreas, thymus, spleen, heart, kidneys, and adrenal glands were removed and weighed. In blood morphological parameters (red blood cell count; haematocrit; mean cell volume; haemoglobin concentration; and white blood cell count, were measured using standard analytical procedures. The following were assayed in serum: total protein, urea $\mathrm{N}$, albumin, creatinine aspartate aminotransferase, alanine aminotransferase, bilirubin, glucose, high density lipoprotein, total cholesterol, triglycerides, $\mathrm{Ca}, \mathrm{Na}, \mathrm{Mg}$, and $\mathrm{K}$ ) using a Vitros DTII analyser following the manufacturer's instructions (Johnson and Johnson).

The results were analysed by one-way analysis of variance using the Statgraphics Plus 2.1 for Windows program, the significance of differences was evaluated with Duncan's test. 


\section{RESULTS AND DISCUSSION}

The chemical composition of tubers from unmodified and genetically modified potato plants is presented in Table 2 . The tubers from $\mathrm{J}_{2}$ plants, modified in the direction of overexpressing 14-3-3 protein, contained much more crude protein

TABLE 2

Chemical composition of dried potato tubers

\begin{tabular}{lccc}
\hline & & \multicolumn{2}{c}{ Diet - potatoes } \\
\cline { 2 - 4 } Item & non-transgenic & \multicolumn{2}{c}{ transgenic line } \\
\cline { 2 - 4 } & Desiree & $\mathrm{J}_{1}$ & $\mathrm{~J}_{2}$ \\
\hline Crude, \% & & & \\
protein & 10.7 & 10.2 & 16.2 \\
$\quad$ fat & 0.2 & 0.3 & 0.6 \\
fibre & 4.2 & 4.2 & 3.6 \\
$\quad$ ash & 4.9 & 4.7 & 5.0 \\
$\mathrm{Ca}$, ppm & 317 & 288 & 344 \\
$\mathrm{Mg}$, ppm & 960 & 964 & 984 \\
$\mathrm{P}, \%$ & 0.32 & 0.35 & 0.34 \\
$\mathrm{Cu}$, ppm & 5.31 & 4.50 & 4.77 \\
$\mathrm{Zn}$, ppm & 29.0 & 22.4 & 33.7 \\
$\mathrm{Na}, \mathrm{ppm}$ & 32.0 & 21.5 & 24.0 \\
$\mathrm{~K}, \%$ & 3.47 & 3.18 & 3.37 \\
$\mathrm{Fe}, \mathrm{ppm}$ & 58.0 & 153 & 130 \\
\hline
\end{tabular}

than the unmodified tubers and those from line $\mathrm{J}_{1}$, which points to the more intensive synthesis of nitrogenous compounds in these plants. The potatoes also contained somewhat less crude fibre and more fat. A positive correlation between increased synthesis of 14-3-3 protein and a higher concentration of fat in potato tubers was also shown by Prescha et al. (2001). It was also found that a significant increase in the nonpolar lipid fraction was associated with the overexpression of this protein. Transgenic potatoes exhibiting overexpression of 14-3-3 protein are characterized by changes in the chemical composition of tubers that are potentially beneficial in terms of nutrition.

The composition of potato tubers from line $\mathrm{J}_{1}$, modified in the direction of repression of the gene encoding ADP-ribosylation factor, only slightly differed from that of unmodified potato tubers.

The differences in composition between genetic forms of potatoes that were used in this experiment could also potentially pertain to the content of compounds not assayed in this study, such as starch, soluble sugars, and regulatory substances. Such effects of genetic modifications in potatoes were found by Kulma et al. (2000), who showed that the overexpression of 14-3-3 protein was connected with 
a high concentration of soluble sugars and epinephrine, whereas its repression was associated with a decreased level of sugars and catecholamines.

Despite a similar ash content in the tubers of the compared potato lines, the concentration of some elements in it was clearly different. Significant differences appeared in the iron content, which was about two times as high, and in sodium, which was clearly lower in $J_{1}$ and $J_{2}$ potatoes than in unmodified ones. Small differences also appeared in the content of zinc, which was lowest in $\mathrm{J}_{1}$ potatoes (Table 2).

The type of potato included in the diet had no effect on the growth rate and therefore on the final body weight of rats after 5 weeks of feeding the experimental and control diets (Table 3). The duration of the experiment on growing animals was sufficient to show the potential effect of anitnutrients or toxins if they were present in the modified potatoes. The absence of differences in body weight gain among the animals supports the conclusion that potatoes modified in the direction of overexpressing 14-3-3 protein and repressing the gene coding ADP ribosylation factor do not contain compounds that are toxic to growing animals.

TABLE 3

Body mass of rats fed experimental diets

\begin{tabular}{|c|c|c|c|c|c|}
\hline \multirow{3}{*}{ Parameter } & \multicolumn{3}{|c|}{ Diet - potatoes } & \multirow{3}{*}{ SEM } & \multirow{3}{*}{$P$} \\
\hline & \multirow{2}{*}{$\begin{array}{c}\text { non- } \\
\text { transgenic } \\
\text { Desiree }\end{array}$} & \multicolumn{2}{|c|}{ transgenic line } & & \\
\hline & & $\mathrm{J}_{1}$ & $\mathrm{~J}_{2}$ & & \\
\hline Initial body mass, $\mathrm{g}$ & 150.6 & 150.1 & 149.7 & 2.200 & 0.964 \\
\hline Final body mass (after 5 weeks), g & 266.4 & 267.1 & 261.2 & 2.377 & 0.142 \\
\hline Total weight gain, $g$ & 115.8 & 117.7 & 111.5 & 2.293 & 0.168 \\
\hline
\end{tabular}

Zduńczyk et al. (personal communication) also failed to find differences in the growth rate of rats fed conventional and genetically modified potato tubers. The results of these authors are not, however, fully comparable with the results of our study since they assessed the impact of a different modification that did not lead to a change in the chemical composition of tubers, moreover, they fed autoclaved potatoes and in larger amounts ( $40 \%$ of the diet).

The nutrient digestibility coefficients of the diets containing the evaluated forms of potatoes differed significantly with the exception of protein digestibility coefficients (Table 4). Organic substances and nitrogen-free extractives of diets containing $\mathrm{J}_{2}$ potatoes were digested slightly but significantly better than in the other diets. The crude fat of diets containing both modified forms was digested better than fat in the diet containing the control potatoes. The largest differences were in the digestibility of crude fibre, which was lowest in the animals receiving unmodified and $\mathrm{J}_{2}$ potatoes, and highest in the diets containing $\mathrm{J}_{1}$ potatoes. The relatively small differences in fat digestibility and somewhat greater differences in fibre digestibility had no effect on the results of the growth experiment. 
TABLE 4

Digestibility of nutrients in experimental diets, $\%$

\begin{tabular}{|c|c|c|c|c|c|}
\hline & \multicolumn{3}{|c|}{ Diet - potatoes } & \multirow{3}{*}{ SEM } & \multirow{3}{*}{$\mathrm{P}$} \\
\hline & \multirow{2}{*}{$\begin{array}{c}\text { non- } \\
\text { transgenic } \\
\text { Desiree }\end{array}$} & \multicolumn{2}{|c|}{ transgenic line } & & \\
\hline & & $\mathrm{J}_{1}$ & $\mathrm{~J}_{2}$ & & \\
\hline Organic matter & $88.25^{\mathrm{a}}$ & $88.57^{\mathrm{a}}$ & $89.88^{b}$ & 0.368 & 0.016 \\
\hline \multicolumn{6}{|l|}{ Crude } \\
\hline protein & 82.96 & 82.36 & 82.98 & 0.607 & 0.747 \\
\hline fat & $91.34^{\mathrm{A}}$ & $94.03^{\mathrm{B}}$ & $94.10^{\mathrm{B}}$ & 0.437 & 0.001 \\
\hline fibre & $25.54^{\mathrm{A}}$ & $42.64^{\mathrm{C}}$ & $31.61^{\mathrm{AB}}$ & 1.989 & 0.000 \\
\hline $\mathrm{N}$-free extractives & $91.49^{\mathrm{A}}$ & $91.42^{\mathrm{A}}$ & $93.34^{\mathrm{B}}$ & 0.420 & 0.005 \\
\hline
\end{tabular}

denoted by different letters $\mathrm{A}, \mathrm{B}$ differ significantly at $\mathrm{P} \leq 0.01$ or $\mathrm{P} \leq 0.05$ means in a row

The differences in digestibilities, especially of fibre and fat, are a surprising result, since they could not have been caused by differences in the digestibility of these substances in potatoes. The main sources of fibre and fat in the diet were cellulose, added in amounts of 3.2 and $3.3 \%$, and soya oil, added at a rate of $4 \%$, whereas the amounts of fat and fibre from potatoes were small and little diversified. This may mean that the cause of the differences in the digestibility of these components, similarly as that of carbohydrates, was the presence in the potatoes of substances modifying the course of digestion or endogenous secretion of fat and fermentation of fibre in the large intestine. Explanation of the causes of the differences found in digestibilities is not possible without conducting physiological studies.

The relative weight of internal organs did not differ significantly (Table 5); there was only a tendency towards a higher weight of caecum tissue in rats fed the transgenic potatoes in comparison with the control group (0.40-0.42 vs 0.31 $\mathrm{g} / 100 \mathrm{~g} \mathrm{BW}$ ). The weight of the caecum tissue depends to a certain degree on the intensity of bacterial fermentation and increases with increased consumption of

TABLE 5

Relative organ mass (g/100 g BW) of rats fed experimental diets

\begin{tabular}{|c|c|c|c|c|c|}
\hline \multirow{3}{*}{ Organ } & \multicolumn{3}{|c|}{ Diet-potatoes } & \multirow{3}{*}{ SEM } & \multirow{3}{*}{$\mathrm{P}$} \\
\hline & \multirow{2}{*}{$\begin{array}{c}\text { non- } \\
\text { transgenic } \\
\text { Desiree }\end{array}$} & \multicolumn{2}{|c|}{ transgenic line } & & \\
\hline & & $\mathrm{J}_{1}$ & $\mathrm{~J}_{2}$ & & \\
\hline Caecum & 0.31 & 0.40 & 0.42 & 0.043 & 0.281 \\
\hline Spleen & 0.20 & 0.19 & 0.18 & 0.007 & 0.318 \\
\hline Pancreas & 0.32 & 0.30 & 0.34 & 0.025 & 0.585 \\
\hline Thymus & 0.25 & 0.23 & 0.24 & 0.014 & 0.755 \\
\hline Heart & 0.33 & 0.34 & 0.32 & 0.008 & 0.408 \\
\hline Kidneys & 0.75 & 0.70 & 0.73 & 0.027 & 0.502 \\
\hline Adrenals & 0.034 & 0.038 & 0.035 & 0.004 & 0.861 \\
\hline Liver & 3.84 & 3.47 & 3.69 & 0.111 & 0.372 \\
\hline
\end{tabular}


carbohydrates that are not digested in the small intestine but undergo fermentation in this part of the gastrointestinal tract, such as pectins or raw potato starch (Pastuszewska et al., 2000). It may therefore be assumed that the modified potatoes had more of such carbohydrates than the controls.

The absence of significant differences in the weight of vital organs and those important in terms of metabolic processes such as the kidneys, liver, pancreas and heart indicates that feeding diets containing genetically modified potatoes does not affect these processes.

TABLE 6

Haematological parameters in rats fed experimental diets

\begin{tabular}{|c|c|c|c|c|c|}
\hline \multirow{3}{*}{ Parameter } & \multicolumn{3}{|c|}{ Diet - potatoes } & \multirow{3}{*}{ SEM } & \multirow{3}{*}{$P$} \\
\hline & \multirow{2}{*}{$\begin{array}{c}\text { non- } \\
\text { transgenic } \\
\text { Desiree }\end{array}$} & \multicolumn{2}{|c|}{ transgenic line } & & \\
\hline & & $\mathrm{J}_{1}$ & $\mathrm{~J}_{2}$ & & \\
\hline Red blood cell count, $10^{12} / 1$ & 6.41 & 6.19 & 6.70 & 0.230 & 0.579 \\
\hline Haematocrit, L/L & 0.36 & 0.35 & 0.37 & 0.012 & 0.830 \\
\hline Mean red cell volume, fL & 56.5 & 51.7 & 55.0 & 2.042 & 0.655 \\
\hline Haemoglobin concentration, $\mathrm{g} / \mathrm{L}$ & 129.5 & 134.5 & 131.0 & 4.212 & 0.853 \\
\hline White blood cell count, $10^{9} / \mathrm{L}$ & 5.5 & 4.8 & 4.9 & 0.760 & 0.757 \\
\hline
\end{tabular}

The basic haematological parameters of rats also showed no significant differences among groups (Table 6) and were within normal values for this species (Sharp and LaRegina, 1998). Among biochemical parameters only total blood cholesterol differed significantly and was lower in rats fed the diet containing $J_{1}$ potatoes than in those given the diet with $\mathrm{J}_{2}$ (Table 7).

Statistically significant differences also occurred in blood sodium and magnesium contents: in the group fed $\mathrm{J}_{2}$ potatoes with overexpression of 14-3-3 protein the sodium content was higher than in the control group, whereas the magnesium content was higher than in the control and $\mathrm{J}_{1}$ groups. These differences cannot be explained by the content of these elements in the potatoes, since the sodium content of $\mathrm{J}_{2}$ tubers was much lower than in the control tubers (21.5 vs 32.0, respectively), the magnesium content, on the other hand, was similar in all of the potatoes (Table 2).

The lack of significant differences in the morphological picture of blood in the basic biochemical parameters of rats in association with the lack of anomalies in the weight and general appearance of internal organs indicate that the normal course of vital functions of the animals is not disordered by the presence of substances having a negative affect of the body. 
Selected biochemical blood parameters in rats fed experimental diets

\begin{tabular}{|c|c|c|c|c|c|}
\hline \multirow{3}{*}{ Parameter } & \multicolumn{3}{|c|}{ Diet - potatoes } & \multirow{3}{*}{ SEM } & \multirow{3}{*}{$\mathrm{P}$} \\
\hline & \multirow{2}{*}{$\begin{array}{c}\text { non- } \\
\text { transgenic } \\
\text { Desiree }\end{array}$} & \multicolumn{2}{|c|}{ transgenic line } & & \\
\hline & & $\mathrm{J}_{1}$ & $\mathrm{~J}_{2}$ & & \\
\hline Total protein, $\mathrm{g} / \mathrm{L}$ & 52.9 & 58.6 & 56.5 & 3.970 & 0.685 \\
\hline Urea $\mathrm{N}, \mathrm{mmol} / \mathrm{L}$ & 2.1 & 1.9 & 2.6 & 0.286 & 0.294 \\
\hline Albumins $\mathrm{g} / \mathrm{L}$ & 32.1 & 35.1 & 31.8 & 2.798 & 0.652 \\
\hline Creatinine, $\mu \mathrm{mol} / \mathrm{L}$ & 35.8 & 32.8 & 33.0 & 2.072 & 0.534 \\
\hline Aspartate aminotransferase, U/L & 179.1 & 178.9 & 192.5 & 21.223 & 0.875 \\
\hline Alamine aminotransferase, $\mathrm{U} / \mathrm{L}$ & 46.3 & 44.6 & 48.3 & 6.903 & 0.933 \\
\hline Bilirubin, $\mu \mathrm{mol} / \mathrm{L}$ & 22.3 & 24.6 & 24.3 & 5.289 & 0.673 \\
\hline Glucose, $\mathrm{mmol} / \mathrm{L}$ & 9.13 & 8.04 & 9.69 & 0.967 & 0.483 \\
\hline High density lipoprotein, $\mathrm{mmol} / \mathrm{L}$ & 1.37 & 1.23 & 1.32 & 0.127 & 0.146 \\
\hline Total cholesterol, mmol/L & $1.62^{\mathrm{ab}}$ & $1.45^{\mathrm{a}}$ & $1.82^{\mathrm{b}}$ & 0.096 & 0.050 \\
\hline Triglycerides, mmol/L & 0.79 & 0.66 & 0.82 & 0.103 & 0.517 \\
\hline $\mathrm{Ca}, \mathrm{mmol} / \mathrm{L}$ & 10.41 & 10.43 & 1.09 & 0.235 & 0.145 \\
\hline $\mathrm{K}, \mathrm{mmol} / \mathrm{L}$ & 5.90 & 5.71 & 6.56 & 0.241 & 0.217 \\
\hline $\mathrm{Na}, \mathrm{mmol} / \mathrm{L}$ & $148.1^{\mathrm{a}}$ & $154.6^{\mathrm{ab}}$ & $163.8^{\mathrm{b}}$ & 3.531 & 0.035 \\
\hline $\mathrm{Mg}, \mathrm{mmol} / \mathrm{L}$ & $2.78^{\mathrm{a}}$ & $2.73^{\mathrm{a}}$ & $3.56^{\mathrm{b}}$ & 0.211 & 0.031 \\
\hline
\end{tabular}

means in a row denoted by different letters at $\mathrm{P} \leq 0.05$

\section{CONCLUSIONS}

Genetic modifications aimed at differentiating the content of 14-3-3 protein in potato plants directly (transgenic line $\mathrm{J}_{2}$ ) or indirectly (transgenic line $\mathrm{J}_{1}$ ) led to a change in the nutritional value of tubers.

Including $20 \%$ dried tubers of both transgenic lines with elevated synthesis of 14-3-3 protein in the diets of rats did not negatively affect the assayed growth parameters, did not decrease the digestibility of nutrients, and also did not change blood morphology or most blood biochemical parameters of the experimental animals.

No negative effect of diets containing transgenic potato tubers were found on rats in terms of the evaluated health parameters, but a complex evaluation of the influence of transgenic dietary components on the health of rats (which are also an experimental model for monogastric animals and humans) requires expanding studies to include, for example, an assessment of allergenic properties and toxicity. 


\section{REFERENCES}

Aitken A., 1996. 14-3-3 and its possible role in co-ordinating multiple signalling pathways. Tr. Cell Biol. 6, 340-347

AOAC, 1990. Association of Official Analytical Chemists, Official Methods of Analysis. $16^{\text {th }}$ Edition. Arlington, VA

Chung H.J., Sehenke P.C., Ferl R.J, 1999. The 14-3-3 proteins: cellular regulators of plant metabolism. Trends Plant Sci. 4, 367-371

Huber S.C., Bachman M., Huber J.L., 1996. Post-translational regulation of nitrate reductase activity - a role for $\mathrm{Ca}^{2+}$ and 14-3-3 proteins. Trends Plant Sci. 1, 432-438

Kulma A., Wilczyński G., Milcarz M., Prescha A., Szopa J., 2000. Modulation of carbohydrate metabolism in transgenic potato through genetic engineering and analysis of rabbits fed on wild type and transgenic potato tubers. Progress in Biotechnology. Food Biotechnol. 17, 19-33

Markiewicz E., Wilczyński G., Rzepecki R., Kulma A., Szopa J., 1996. The 14-3-3 protein binds to the nuclear matrix endonuclease and has a possible function in the control of plant senescence. Cell. Mol. Biol. Lett. 1, 391-415

Pastuszewska B., Kowalczyk J., Ochtabińska A., 2000. Dietary carbohydrates affect caecal fermentation and modify nitrogen excretion patterns in rats. II. Studies with diets differing in protein quality. Arch. Anim. Nutr. 53, 335-352

Prescha A., Świędrych A., Biernat J., Szopa J., 2001. Increase in lipid content in potato tubers modified by 14-3-3 gene overexpression. J. Agr. Food Chem. 49, 3638-3643

Sehnke P.C., Chung H.J., Wu K., Ferl R.J., 2001. Regulation of starch accumulation by granule-associated plant 14-3-3 proteins. Proc. Nat. Acad. Sci. USA 98, 765-770

Sharp P.E., LaRegina M.C., 1998. The laboratory rat. M.A. Suckow (Editor). CRC Press, Washington, DC

Szopa J., Muller-Rober B., 1994. Cloning and expression analysis of an ADP-ribosylation factor from Solanum tuberosum L. Plant Cell Rep. 14, 180-183

Szopa J., Wróbel M., Matysiak-Kata I., Świędrych A., 2001. The metabolic profile of the 14-3-3 repressed transgenic potato tubers. Plant Sci. 161, 1075-1082

Wilczyński G., Kulma A., Feiga I., Wenczel A., Szopa J., 1998a. Manipulating of 14-3-3 protein expression result in the changes of catecholamine content in potato plants. Cell. Mol. Biol. Lett. 3, 75-91

Wilczyński G., Kulma A., Szopa J., 1998b. The expression of 14-3-3 isoforms in potato is developmentally regulated. J. Plant Physiol. 153, 118-126

Żuk M., Prescha A., Kępczyński J., Szopa J., 2003. ARF regulates metabolism and antioxidant capacity of transgenic potato tubers. J. Agr. Food. Chem. 51, 288-294 


\section{STRESZCZENIE}

\section{Wpływ skarmiania bulw genetycznie modyfikowanych roślin ziemniaka z nadekspresją białka 14-3-3 i czynnika ADP-rybosylacji na metabolizm i stan zdrowia szczurów laboratoryjnych}

Porównano wpływ podawania szczurom bulw transgenicznych ziemniaków wykazujących nadekspresję białka 14-3-3 (linia $\mathrm{J}_{2}$ ) i represję czynnika ADP-rybosylacjii (linia $\mathrm{J}_{1}$ ) oraz ziemniaków linii kontrolnej - Desiree. Ziemniaki linii $\mathrm{J}_{2}$ zawierały znacznie więcej białka ogólnego (16,2\% w s.m.) w porównaniu z ziemniakami kontrolnymi $(10,7 \%)$ i linii transgenicznej $\mathrm{J}_{1}$. Modyfikacja białka 14-3-3 i czynnika ADP-rybosylacji wpłynęła także na zróżnicowanie składu mineralnego, szczególnie koncentracji Fe. Żywienie szczurów przez 5 tygodni izobiałkowymi dietami zawierającymi 20\% suszu z transgenicznych lub nietransgenicznych ziemniaków nie miało istotnego wpływu na wzrost zwierząt, nie wpłynęło negatywnie na strawność składników pokarmowych - strawność tłuszczu i włókna w bulwach ziemniaków transgenicznych $\mathrm{J}_{1}$ i $\mathrm{J}_{2}$ była większa, a strawność masy organicznej ziemniaków $\mathrm{J}_{2}$ była istotnie większa. Względna masa wybranych organów wewnętrznych, parametry morfologiczne i większość parametrów biochemicznych krwi nie różniły się istotnie statystycznie w grupach szczurów otrzymujących diety zawierające susz z transgenicznych i nietransgenicznych ziemniaków. 